\title{
Management of Subclinical Hypothyroidism
}

Shaheda Ahmed
A S M Towhidul Alam²

'Department of Biochemistry BGC Trust Medical College, Chandanyaish Chittagong, Bangladesh.

${ }^{2}$ Department of Biochemistry Cox's Bazar Medical College Cox's Bazar, Bangladesh.
${ }^{*}$ Correspondence to:

\section{Dr. Shaheda Ahmed} Department of Biochemistry BGC Trust Medical College, Chandanyaish Chittagong, Bangladesh.

Mobile: +8801715704218

E-mail: perveen71@gmail.com

\begin{abstract}
Objective: To review current concepts in the management of subclinical hypothyroidism $(\mathrm{SCH})$ in patients with non-specific symptoms. Data sources: A review of articles reported on overt hypothyroidism and subclinical hypothyroidism. Summary of review: In a patient with primary overt hypothyroidism, management is usually straightforward: treatment with thyroxine should be offered to anyone with characteristic clinical features, a raised serum thyroid stimulating hormone (TSH) concentration and a low serum thyroxine $\left(\mathrm{T}_{4}\right)$ concentration. More difficult is the management of a patient with subclinical hypothyroidism $(\mathrm{SCH})$, in whom serum TSH is slightly raised (5-20 mIU/L) but $\mathrm{T}_{3}, \mathrm{~T}_{4}$ levels are normal, and who is either asymptomatic or has only non-specific symptoms. Left untreated, some of these patients will eventually develop overt hypothyroidism. This review will address the use of thyroxine in patients with subclinical hypothyroidism.
\end{abstract}

Key words: Subclinical hypothyroidism; $\mathrm{TSH} ; \mathrm{T}_{3} ; \mathrm{T}_{4}$.

\section{INTRODUCTION}

The term subclinical hypothyroidism is used to describe the finding of a mildly elevated serum TSH $(5-20 \mathrm{mIU} / \mathrm{L})$ but a normal free thyroxine $\left(\mathrm{T}_{4}\right) \cdot{ }^{1} \mathrm{~T}_{3}$ is not a sensitive indicator for hypothyroidism ${ }^{1}$. In the community, the most common etiology is chronic autoimmune thyroiditis ${ }^{1}$.

Subclinical hypothyroidism or mild thyroid failure is a common problem, with a prevalence of $3 \%$ to $8 \%$ in the population without known thyroid disease ${ }^{2}$. In the original Wickham survey in Northeast England, $8 \%$ of women $(10 \%$ of women over 55 years of age) and 3\% of men had subclinical hypothyroidism ${ }^{3}$. In the Colorado study, $9.4 \%$ of the subjects had a high-serum TSH concentration, of which $9.0 \%$ had subclinical hypothyroidism ${ }^{4}$. Among those with a high serum TSH concentration, $74 \%$ had a value between 5.1 and $10 \mathrm{mIU} / \mathrm{L}$ and $26 \%$ had a value $>10 \mathrm{mIU} / \mathrm{L}$. The percentage of subjects with a high-serum TSH concentration was higher for women than for men in each decade of age, and ranged from $4 \%$ to $21 \%$ in women and $3 \%$ to $16 \%$ in men. In the National Health and Nutritional Examination Survey (NHANES III) serum TSH concentrations increased with age in both men and women and were higher in whites than in blacks, independent of serum anti-thyroid antibody concentration ${ }^{5}$. Serum TSH greater than the population defined upper limit of the reference range of $4.5 \mathrm{mIU} / \mathrm{L}$ of whom only $40 \%$ were anti-thyroid antibody positive $^{6}$. More recent data from Birmingham suggest that there is now an increased awareness of thyroid disease and testing of thyroid function and perhaps earlier use of levothyroxine in $\mathrm{SCH}^{7}$.

Spontaneous recovery has also been described in subjects with subclinical hypothyroidism, although the frequency of this phenomenon is unclear. In one study, $37 \%$ of patients normalized their serum TSH levels over a mean follow-up time of 32 months $^{8}$. Normalization of serum TSH concentration is more likely to occur in patients with negative antithyroid antibodies and serum TSH levels $<10 \mathrm{mIU} / \mathrm{L}$, and within the first 2 years after diagnosis ${ }^{1}$. 


\section{NORMAL THYROID FUNCTION}

There are two thyroid hormones, 3, 5, 3-triiodo-L-thyronine $\left(T_{3}\right)$ and L-thyroxine $\left(T_{4}\right) . T_{3}$ is the active hormone whereas $T_{4}$ functions as a circulating thyroid hormone store. $\mathrm{T}_{3}$ binds to nuclear receptors to increase oxygen consumption (by stimulating $\mathrm{Na}^{+}-\mathrm{K}^{+}$- ATPase and activating mitochondrial metabolic pathway) and regulates lipid and carbohydrate metabolism and normal growth and maturation of tissues?.

Thyroid function is controlled by thyroid stimulating hormone, which in turn is controlled by thyrotropin releasing hormone (TRH). The major function of TRH is to release TSH from the adenohypophysis. TSH is released from adenohypophysis in response to TRH and the negative feedback effects of $\mathrm{T}_{3}$ and $\mathrm{T}_{4}$. By binding to specific thyroid follicular cell surface receptors and activating adenylate cyclase, TSH stimulates synthesis and release of $\mathrm{T}_{3}$ and $\mathrm{T}_{4}$ from thyroid gland. Thyroid hormones circulate either free $\mathrm{T}_{3}\left(\mathrm{FT}_{3}\right)$ or free $\mathrm{T}_{4}\left(\mathrm{FT}_{4}\right)$ (i.e. the active form) or bound form. Approximately $99.98 \%$ of the circulating $\mathrm{T}_{4}$ is bound and $99.8 \%$ of the circulating $\mathrm{T}_{3}$ is bound ${ }^{10}$.

\section{THYROID FUNCTION TESTS}

Serum TSH: Extremely sensitive (fourth generation) TSH assays can detect TSH level $<$ or $=0.004 \mathrm{mIU} / \mathrm{L}$, but for practical purposes assays sensitive to $<$ or $=0.1 \mathrm{mIU} / \mathrm{L}$ are sufficient. Using two specific monoclonal antibodies, the ultrasensitive TSH assay has improved the sensitivity of the TSH assay to the extent that both hypo and hyperthyroid states may be discriminated from the euthyroid state using this measurement ${ }^{11-12}$.

In secondary (i.e. pituitary) hypothyroidism, the circulating TSH levels may be within the normal range, although they are always low relative to the circulating $\mathrm{FT}_{4}$ levels. ${ }^{13}$ The TSH levels are suppressed by adequate $\mathrm{T}_{4}$ replacement in patients with primary hypothyroidism, but 4-6 weeks should be allowed after changing the doses of $\mathrm{T}_{4}$ to allow adequate equilibration of thyroxine with tissues before measuring TSH levels ${ }^{13}$.

Free thyroxine: The $\mathrm{FT}_{4}$ assay is a radioimmuno-assay that uses a $T_{4}$ tracer to measure the non-protein bound $T_{4}$. The free hormone concentrations correlate well with the metabolic state and should always be used to assess thyroid status. It is often performed as a second-line test to investigate an abnormal TSH level. In early primary hypothyroidism, the TSH is a more sensitive test than the $\mathrm{FT}_{4}$, which may be within the normal range ${ }^{14}$.

Free triiodothyronine: The $\mathrm{FT}_{3}$ assay is a radio-immunoassay that uses a $\mathrm{T}_{3}$ analogue tracer to measure the non-protein bound $\mathrm{T}_{3}$ fraction. The $\mathrm{FT}_{3}$ estimation is not a useful test to detect hypothyroidism because low levels only occur late in the disease.

The normal, lower border line, upper border line and TSH, $\mathrm{FT}_{3}$ and $\mathrm{FT}_{4}$ levels diagnostic of primary hypothyroidism are listed in table $-1^{14}$.

Table 1 : Free thyroid hormone levels in healthy and in primary hypothyroid

\begin{tabular}{lllll} 
& $\begin{array}{l}\text { Primary } \\
\text { Hypothyroid }\end{array}$ & $\begin{array}{l}\text { Lower } \\
\text { Borderline }\end{array}$ & Normal & $\begin{array}{l}\text { Upper } \\
\text { borderline }\end{array}$ \\
TSH $(\mathrm{mIU} / \mathrm{L})$ & $>4.5$ & $0.2-0.4$ & $0.5-3.5$ & $3.6-4.5$ \\
FT4 $(\mathrm{pmol} / \mathrm{L})$ & $<8$ & $8-12$ & $13-23$ & $24-26$ \\
\hline
\end{tabular}

Total $\mathrm{T}_{4}$ : The total $\mathrm{T}_{4}$ measurement includes the protein bound as well as the $\mathrm{FT}_{4}$ fraction, and is subject to false interpretation of the thyroid status when there are abnormalities of thyroid binding proteins ${ }^{14}$.

Other tests: Ultrasonography is usually performed first to assess thyroid masses, to detect whether the enlargement is cystic, solid or multinodular ${ }^{14}$.

\section{BENEFITS OF LEVOTHYROXINE THERAPY IN NON- PREGNANT SUBJECTS}

Although studies have pointed to some adverse effects of SCH, no consensus exists as to the clinical importance of the adverse effects and the benefits of levothyroxine therapy, particularly for the $80 \%$ of the patients with $\mathrm{SCH}$ who have a TSH of less than $10 \mathrm{mIU} / \mathrm{L}^{2}$.

\section{PROGRESSION TO OVERT HYPOTHYROIDISM}

Patients with SCH have a high rate of progression to clinically overt hypothyroidism, $2.6 \%$ each year if thyroperoxidase (TPO) antibodies are absent and $4.3 \%$ if they are present. A TSH level greater than $10 \mathrm{mIU} / \mathrm{L}$ predicts a higher rate of progression, and a level of less than $6 \mathrm{mIU} / \mathrm{L}$ predicts a lower likelihood of progression. In a study in men and women older than 55 years with a mean follow-up of 32 months, the TSH level normalized in $52 \%$ of those with a serum TSH less than $10 \mathrm{mIU} / \mathrm{L}^{2}$.

\section{SCREENING FOR SCH}

Uniform national guidelines for screening for thyroid disease with serum TSH levels have not been established. However, because of the high prevalence of $\mathrm{SCH}$ and associated metabolic risk factors such as hyperlipidemia, the American Thyroid Association recommends screening by measurement of serum TSH beginning at age 35 years and every 5 years thereafter. The evidence in favour of screening is particularly compelling in women, but it can also be justified for men as a relatively cost-effective measure in the context of the periodic health examination. Before recommending routine screening of the general population, large-scale randomized trials are needed to prove that treatment will improve quality of life in otherwise healthy patients who have the mildly elevated TSH level (5-10 $\mathrm{mIU} / \mathrm{L}$ ) typical of most $\mathrm{SCH}$ cases. Many thyroidologists advocate routine screening before and during pregnancy ${ }^{2}$. Screening of thyroid function and autoantibodies are not recommended for every women, but should be performed in first trimester, in those with a personal or family history of thyroid disease, goitre, other autoimmune disease including type I diabetes or when there is clinical suspicion of thyroid dysfunction ${ }^{1}$.

\section{MANAGEMENT OF SCH DURING PREGNANCY}

One situation where opinion is consistent with regard to treatment of $\mathrm{SCH}$ with thyroxine is in the context of pregnancy or desire for conception. There is evidence that miscarriage rates and rates of premature delivery are lower if $\mathrm{SCH}$ is treated with thyroxine, and indeed some evidence that thyroxine treatment of biochemically euthyroid women with thyroid autoimmunity improves pregnancy outcome, which coupled with evidence that even mild thyroid hormone deficiency is associated with an adverse effect on childhood neurodevelopment, has led specialist associations and expert groups to support role of thyroxine treatment ${ }^{15-18}$. 
Recent research suggests that inadequate maternal $\mathrm{T}_{4}$ therapy is associated with impaired cognitive development in their offspring ${ }^{1}$. Evidence of clinical benefit, though limited, broadly suggests that it is better to treat subclinical hypothyroidism before overt hypothyroidism develops. Such a strategy should reduce the risk of loss to follow-up and subsequent morbidity of a delayed diagnosis of profound hypothyroidism ${ }^{19}$. Unless contraindicated; iodine supplementation should be prescribed routinely in women planning a pregnancy. The National Health and Medical Research Council recommend an iodine supplement of $150 \mathrm{gm}$ each day ${ }^{20}$. Maternal thyroid functions during pregnancy changes in response to the increased metabolic requirements and the presence of the fetus. In addition, thyrotrophic activity of -hCG results in a decrease in TSH and increase in $\mathrm{FT}_{4}$ and $\mathrm{FT}_{3}$ in the first trimester, ${ }^{1,21}$. In later pregnancy $\mathrm{FT}_{4}$ and $\mathrm{FT}_{3}$ are lower. Binding globulin levels are induced by estrogen, so total $\mathrm{T}_{4}$ and $\mathrm{T}_{3}$ levels are invariably high $^{1}$. The following ranges of TSH have been provided by the American Thyroid Association ${ }^{21}$.

- First trimester 0.1- 2.5 mIU/L

- Second trimester 0.2-3.0 mIU/L

- Third trimester 0.3-3.0 mIU/L.

Table 2 : Definition and management of SCH during pregnancy

\begin{tabular}{|c|c|c|c|}
\hline & Definition & Concern & Recommended Action ${ }^{1,21}$ \\
\hline $\begin{array}{l}\text { Subclinical } \\
\text { hypothyroidism } \\
\text { (SCH) } \\
\text { (Prevalence } \\
2-2.5 \%)\end{array}$ & $\begin{array}{l}\text { TSH between } \\
2.5-10 \text { with } \\
\text { normal } \mathrm{T}_{4}\end{array}$ & $\begin{array}{l}\text { TPO Ab positivity may } \\
\text { in itself be associated } \\
\text { with fetal miscarriage } \\
\text { and levothyroxine } \\
\text { intervention in TPO } \\
\text { antibody positive women } \\
\text { with SCH may be } \\
\text { beneficial }^{22} \text {. } \\
\text { Levothyroxine dose } \\
\text { should be increase by } \\
30-50 \% \text { from early } \\
\text { pregnancy. }\end{array}$ & $\begin{array}{l}\text { Options include treatment } \\
\text { with levothyroxine to } \\
\text { normalize maternal serum } \\
\text { TSH or } 4 \text { weekly } \\
\text { monitoring of TSH. Obtain } \\
\text { TPO Ab levels while } \\
\text { awaiting specialist review. } \\
\text { Monitoring to maintain } \\
\text { TSH results within } \\
\text { trimester specific reference } \\
\text { range is recommended in } \\
\text { early pregnancy and at } \\
\text { least once in each } \\
\text { trimester. }\end{array}$ \\
\hline
\end{tabular}

\section{MANAGEMENT OF SCH IN NON-PREGNANT ADULTS}

Serum TSH concentration of 3 to $5 \mathrm{mIU} / \mathrm{L}$

Levels between 3 and $5 \mathrm{mIU} / \mathrm{L}$ are unlikely to indicate a clinically important abnormality, and levothyroxine therapy at these levels may or may not provide a benefit. Although persons with a serum TSH level of 3 to $5 \mathrm{mIU} / \mathrm{L}$ may be at higher risk of progression to hypothyroidism, no firm evidence of health consequences exists. In a randomized 12 week study of patients with symptoms suggestive of hypothyroidism with serum TSH in the upper normal range, no difference in cognitive and psychological function was observed between levothyroxine - treated and control groups. Given these findings, intervention cannot be recommended for this group, but followup by serum TSH measurement in 1 year would be a reasonable approach, particularly if antithyroid antibodies are detected ${ }^{2}$.

\section{Serum TSH concentration of 5-10 mIU/L}

Where the TSH is consistently between 5-10 mIU/L and the patient is symptomatic, a 3-6 month trial of levothyroxine replacement is appropriate.
Treatment can be continued where there is symptomatic benefit. Where the TSH is between $5-10 \mathrm{mIU} / \mathrm{L}$ and there is the presence of anti-TPO antibodies, an alternative option to thyroxine therapy would be annual thyroid function tests for the early detection of progression to frank hypothyroidism. In contrast, where the patient is antithyroid antibody negative, 3yearly thyroid function tests are considered sufficient ${ }^{23}$.

\section{Serum TSH concentration greater than $10 \mathrm{mIU} / \mathrm{L}$}

Most thyroidologists agree that all patients with $\mathrm{SCH}$ and a serum TSH level above $10 \mathrm{mIU} / \mathrm{L}$ should be treated with levothyroxine ${ }^{2,24}$. Studies have shown that levothyroxine therapy results in an 8-mg reduction in low-density lipoprotein levels. Among the factors that predict response of lipid levels to levothyroxine therapy are higher levels of TSH, insulin resistance, higher levels of pretherapy cholesterol and type III hyperlipidemia. Some evidence suggests nerve conduction, cardiac function, and cognitive and psychological function, with improvement after levothyroxine therapy ${ }^{2}$. An algorithm for the management of subclinical hypothyroidism in the nonpregnant adult is shown in Figure 1.

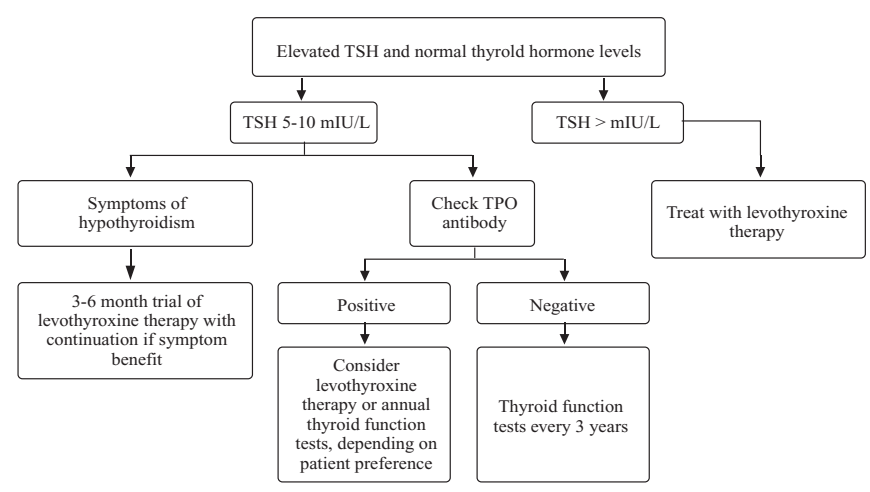

Figure 1: Algorithm for management of subclinical hypothyroidism in the nonpregnant adult Adapted from Vaidya B, Pearce SHS. Management of hypothyroidism in adults. BMJ 2008; 337:284-289.

\section{LEVOTHYROXINE THERAPY FOR SCH}

Where treatment is commenced, an initial dose of levothyroxine of 25-50 gm/day can be used with a target TSH level between 1.0 and $3.0 \mathrm{mIU} / \mathrm{L}$. The TSH level should be measured at 6-8 weeks after commencement of therapy as effect of levothyroxine on TSH lasts for 4-6 weeks ${ }^{2,25}$.

\section{CONCLUSION}

Initiating levothyroxine replacement therapy is recommended for all patients of SCH with a TSH level greater than $10 \mathrm{mIU} / \mathrm{L}$. However, treatment of patients with a serum TSH level between 5 and $10 \mathrm{mIU} / \mathrm{L}$ remains controversial. The strongest arguments for levothyroxine therapy are presence of anti-TPO antibodies, goitre, the possible improvement of quality of life, high risk of progression to overt hypothyroidism and the possibility that $\mathrm{SCH}$ is a cardiovascular risk factor. In patients who are antibody - negative warrants observation rather than immediate treatment as it may be a transient phenomenon. The aim of levothyroxine therapy should be to restore serum TSH concentration to within reference range: levels below this range are possibly associated with an increased risk of developing atrial fibrillation. 
Serum TSH concentration of 3 to $5 \mathrm{mIU} / \mathrm{L}$ recommends follow up particularly if antithyroid antibody are detected. Management of SCH during pregnancy with TSH 3-5 mU/L needs use of levothyroxine with or without positive TPO antibody, as the aim of treatment to keep TSH below $3 \mathrm{mIU} / \mathrm{L}$ and to prevent fetal loss in TPO antibody positive cases. All pregnant women with upper border range (TSH 3-5 mIU/L) should be treated with levothyroxine. Levothyroxine intervention in TPO antibody positive women with $\mathrm{SCH}$ is more beneficial to prevent fetal loss.
Suggested: Initiating levothyroxine replacement therapy is recommended for all patients of SCH with a TSH level greater than $10 \mathrm{mIU} / \mathrm{L}$. However, treatment of patients with a serum $\mathrm{TSH}$ level between 5 and $10 \mathrm{mIU} / \mathrm{L}$ remains controversial. In patients who are antibody - negative warrants observation rather than immediate treatment. Serum TSH concentration of 3 to $5 \mathrm{mIU} / \mathrm{L}$ recommends follow up particularly if antithyroid antibody are detected. Management of SCH during pregnancy with TSH 3-5 mU/L needs use of levothyroxine with or without positive TPO antibody, to keep TSH below $3 \mathrm{mIU} / \mathrm{L}$ and to prevent fetal loss in TPO antibody positive cases.

\section{DISCLOSURE}

All the authors declared no competing interest.

\section{REFERENCES}

1. M.W.J. Strachan, B.R. Walker. Endocrine disease. In: Nicki R. Colledge, Brian R. Walker, Stuart H. Ralston,editors. Davidson's Principles and Practice of Medicine. $21^{\text {st }}$ ed. Oxford: Churchill Livingstone Elsevier. 2010; 338,741-753.

2. Fatourechi V: Subclinical Hypothyroidism: An update for Primary Care Physicians. Mayo Clin Proc. 2009;84(1):65-71.

3. Tunbridge WM, Evered DC, Hall R, Appleton D, Brewis M, Clark F, Evans JG, Young E, Bird T, Smith PA. The spectrum of thyroid disease in the community: the Whickham survey. Clin Endocrinol (Oxf). 1977; 7:481-493.

4. Canaris GJ, Manowitz NR, Mayor G, Ridgway EC. The Colorado thyroid disease prevalence study. Arch Intern Med. 2000; 160:526-534.

5. Hollowell JG, Staehling NW, Flanders WD, Hannon WH, Gunter EW, Spencer CA, Braverman LE. Serum TSH, T, and thyroid antibodies in the United States population (1988-1994): National Health and Nutrition Examination Survey (NHANES III ). J Clin Endocrinol Metab. 2002; 87:489-499.

6. Surks MI, Hollowell JG. Age-specific distribution of serum thyrotropin and anti-thyroid antibodies in the US population: implications for the prevalence of subclinical hypothyroidism. J Clin Endocrinol Metab. 2007;92:4575-4582.

7. Wilson S, Parle JV, Roberts LM, Roalfe AK, Hobbs FD, Clark P, Sheppard MC, Gammage MD, Pattison HM, Franklyn JA. Prevalence of subclinical thyroid dysfunction and its relation to socioeconomic deprivation in the elderly: a community-based cross-sectional survey. J Clin Endocrinol Metab. 2006;91:4809-4816.

8. Meyerovitch J, Rotman-Pikielny P, Sherf M, Battat E, Levy Y, Surks MI. Serum thyrotrophin measurements in the community: fiveyear follow-up in a large network of primary care physicians. Arch Intern Med. 2007;167:1533-1538.

9. Davis PJ, Davis FB. Nongenomic actions of thyroid hormone. Thyroid. 1996;6:497.

10. Grifffiths EC. Clinical applications of thyrotropin releasing hormone. Clin Sci. 1987;73:449-457.

11. J. Larry Jameson, Anthony P. Weetman. Disorders of the thyroid gland. In: Fauci, Braunwald, Kasper, Hauser, Longs, Jameson, Loscalzo, editors. Harrison's Principles of Internal Medicine. $17^{\text {th }}$ ed. New York. Mc Graw Hill companies. 2008;2228-2233.

12. Dayan CM. Interpretation of thyroid function tests. Lancet. 2001;357:619-624.

13. Bakiri F. TSH determination in central hypothyroidism. Ann Endocrinol. 1999;60:422-426.

14. Bethune JE. Interpretation of thyroid function tests. Dis Mon. 1989; 35:541-596.

15. Krasses, G.E. ,Poppe, K \&Glinoer, D. Thyroid function and human reproductive health. Endocrine Reviews. 2010; 31:702-755.

16. Thangaratinam S, Tan A, Knox E, Kilby MD, Franklyn J, Coomarasamy A. Association between thyroid autoantibodies and miscarriage and preterm birth: meta-analysis of evidence. BMJ. 2011; 342: d2616.

17. Haddow JE, Palomaki GE, Allan WC, Williams JR, Knight GJ, Gagnon J, O'Heir CE, Mitchell ML, Hermos RJ, Waisbren SE, Faix JD, Klein RZ. Maternal thyroid deficiency during pregnancy and subsequent neuropsychological development of the child. N. Engl. J. Med. 1999; 341:549-555.

18. Surks MI, Ortiz E, Daniels GH, Sawin CT, Col NF, Cobin RH, Franklyn JA, Hershman JM, Burman KD, Denke MA, Gorman C, Cooper RS, Weissman NJ. Subclinical thyroid disease: scientific review and guidelines for diagnosis and management. JAMA. 2004; $291: 228-238$

19. Vanderpump MPJ, Ahlquist JAO, Franklyn JA and Clayton RN. Consensus statement for good practice and audit measures in the management of hypothyroidism and hyperthyroidism. BMJ. 1996; 313:539- 544.

20. Public statement: Iodine supplementation for pregnant and breast feeding women. National health and Medical Research Council. January, 2010

21. Stagnaro-Green A, Abalovich M, Alexander E, Azizi F, Mestman J, Negro R, Nixon A, Pearce EN, Soldin OP, Sullivan S, Wiersinga W. Guidelines of the American Thyroid Association for the diagnosis and management of thyroid disease during pregnancy and postpartum. Thyroid. 2011; 21:1081-1125.

22. Negro R, Schwartz A, Gismondi R, Tinelli A, Mangieri T, Stagnaro-Green A. Universal screening versus case finding for detection and treatment of thyroid hormonal dysfunction during pregnancy. J Clin Endocrinol Metab. 2010; 95:1699-1707.

23. Vanderpump MPJ. How should we manage patients with mildly increased serum thyrotropin concentrations? Clin Endocrinol. 2010; 72:436-440.

24. American Association of Clinical Endocrinologists. Thyroid Guidelines Committee. AACE medical guidelines for clinical practice for the evaluation and treatment of hyperthyroidism and hypothyroidism. Endocr Pract. 2002; 8:457-469.

25. Vaidya B, Pearce SHS. Management of hypothyroidism in adults. BMJ. 2008; 337:284-289. 